TI 2016-018/VIII

Tinbergen Institute Discussion Paper

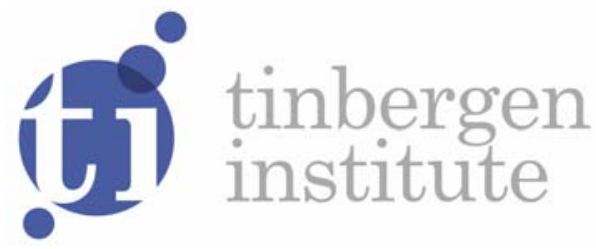

\title{
Spatial Planning and Segmentation of the Land Market
}

\author{
Or Levkovich
}

Jan Rouwendal*

*Tinbergen Institute, the Netherlands

Faculty of Economics and Business Administration, VU University Amsterdam, the Netherlands. 
Tinbergen Institute is the graduate school and research institute in economics of Erasmus University Rotterdam, the University of Amsterdam and VU University Amsterdam.

More $\mathrm{Tl}$ discussion papers can be downloaded at http://www.tinbergen.nl

Tinbergen Institute has two locations:

Tinbergen Institute Amsterdam

Gustav Mahlerplein 117

1082 MS Amsterdam

The Netherlands

Tel.: +31(0)205251600

Tinbergen Institute Rotterdam

Burg. Oudlaan 50

3062 PA Rotterdam

The Netherlands

Tel.: +31(0)10408 8900

Fax: +31(0)104089031 


\title{
Spatial Planning and Segmentation of the Land Market
}

\section{Or Levkovich ${ }^{1}$ and Jan Rouwendal ${ }^{1,2}$}

${ }^{1}$ Department of Spatial Economics, VU University, De Boelelaan 1105, 1081 HV Amsterdam.

2 Tinbergen Institute, Gustav Mahlerplein 117, 1082 MS, Amsterdam

This version: March 72016

Key words: land use policy, spatial planning, land prices

JEL codes: R52, R21, R33

\begin{abstract}
In this paper we provide evidence of segmentation of the Dutch land markets by spatial planning into three compartments referring to agricultural, industrial and residential use. We analyze transactions of ready-to-be developed land provided by the Dutch Land Register (Kadaster) and find that residential land is much more expensive than industrial land. We also compare the prices observed in these transactions with prices for agricultural land in the vicinity and find that agricultural land is much cheaper than residential and industrial land.
\end{abstract}

\section{Acknowledgements}

Financial support from ERC Advanced Grant OPTION (\#246969) is gratefully acknowledged. We thank Lars Brugman and Ramona van Marwijk (Kadaster) for help with collecting and interpreting the data. We also thank Eric Koomen for providing Dutch land use data and maps. 


\section{Introduction}

Many countries and cities engage in active land use policies, often by imposing restrictions. It has been argued in a recent literature that such restrictions can be harmful. Especially when they are rigidly imposed a serious distortion of the allocation of land can result, for instance by freezing an existing situation while economic forces call for substantial changes in land use. However, in many situations restrictions can be adjusted. Sometimes the rules are in fact quite easy to change and behind the apparent rigidity there may be a lot of flexibility. The associated costs may still be non-negligible but the ultimate impact of land use policies on land use and land prices will probably be small. In this paper we will consider the rigidity of land use restrictions by elaborating this simple idea: if land use restrictions can be lifted easily - for instance by asking a permit or contacting the relevant civil servants or local politicians - then they will have little effect on land prices. Only if existing restrictions are believed to persist into the foreseeable future can they have a substantial impact.

Rigid restrictions on land use can lead to segmentation of the land market. For instance, land in the vicinity of a growing city on which only agricultural activities are allowed will be of low value when this restriction is expected to persist, whereas its price may be much higher when it can be transformed to residential or industrial use in the near future. ${ }^{1}$ Similarly, and more important for the purposes of this paper: if restrictions on residential land use are much tighter than those on industrial land use, the price of residential land can be much higher than that of industrial land. Put differently: restrictions on specific types of land use that are believed to persist in the future are reflected in potentially substantial differences in the price of land on which such uses are restricted. If this happens the land market becomes artificially segmented by spatial planning policy into parts on which various uses are allowed.

A large recent literature has paid attention to the impact of land use restrictions on the prices of housing and residential land. Some of these analyses have also considered the implications of such policies on employment and wage growth. There has, however, been less attention for land use policy that relates to firms and their land use. It is, nevertheless, possible and to some extent likely that there will be different implications of land use policy with respect to housing and firms. For instance, the homevoter or influential land user hypotheses (Fischel, 2001; Hilber \& Robert-Nicoud, 2013) especially concerns residential land use. Nevertheless it is reasonable to expect that homeowners and landowners who want to preserve or increase the value of their property by restrictions on residential land use will also think about restrictions with respect to industrial land use. Such restrictions may prevent externalities, but it is equally clear that they may prevent increases in local employment that may be beneficial for the value of land an houses. It may therefore be an attractive strategy for such homevoters and land owners to limit

\footnotetext{
${ }^{1}$ See Capozza and Helsley (Capozza \& Helsley, 1989).
} 
residential development more than commercial development, since the latter may actually contribute to the value of one's property.

In this paper we study this issue by analyzing the prices of newly developed residential and industrial land in the Netherlands, while we also compare them to those of nearby agricultural land. The Netherlands is a densely populated country. The whole country is zoned and local land use plans determine which functions are allowed on a particular site. Urban growth is facilitated by developing plans for (often) substantial extensions of existing urban areas. After acceptance by the local government existing land use restrictions are lifted and the land is made ready for realization of the plans. Residential development is usually undertaken by a few large developers who act in close cooperation with the municipality, which is usually responsible for the necessary infrastructure, to realize the planned design of the new area. Prices of new housing are set by the developers at an estimated market level and if demand is weaker than expected, construction is slowed down so as to prevent losses. ${ }^{2}$ Such coordinated action is uncommon for commercial development where land is also made available by municipalities, but the final user often involved in the actual development. Hence there appear to be two different regimes for residential and industrial or commercial development and the general impression is that land use restrictions on the former are much more tight than on the latter.

The primary purpose of this planning process it to facilitate urban development and to ensure that it takes an orderly course. It seems possible that it does so without imposing significant restrictions on this development. If true, then one would expect the price of land just outside existing urban areas to reflect the pattern described by Capozza and Helsley (1989). That is, the value of agricultural land reflects the anticipated benefits of a future switch to an urban function and there would not be a sudden change in the value of the land when the switch is in fact realized. Although Capozza and Helsley (1989) use a monocentric model in which there is only residential use at the edge of the growing city they consider, the same logic would imply that there will be no switch in the value of land that is transformed from agricultural to commercial use. And one would expect the prices of newly developed industrial and residential at locations close to each other to be equal, provided that the conversion costs are properly taken into account.

However, if land use policy is restrictive, changes in the land use plan that enable the possibility of a switch from agricultural to residential or commercial use could imply a substantial change in the value of the land and the prices of land designated for residential and industrial proposes can be different. This observation is the focal point of the empirical analysis of this paper. We

\footnotetext{
${ }^{2}$ Developers often buy the land from the municipality before constructing houses on it and the price they have to pay for the land is often determined by the municipality as the difference between the price of the house that will be constructed on it and the construction cost.
} 
compare the values of land designed for residential or commercial use in planned extensions of existing urban areas and compare them to the value of agricultural land in the proximity that is not part of the planned extension. If the model of Capozza and Helsley (1989) were approximately true, we would not expect substantial differences between the prices of the three types of land. However, if price differences are substantial, we should conclude that land use policy in the Netherlands does not only facilitate urban development, but also restricts it in comparison to what the market would do.

The paper is organized as follows. In the next section we review some relevant literature about the impact of land use regulation on house prices. Section 3 discusses the data and demonstrates the segmentation of the land market into three compartments. To interpret the findings, section 4 develops a model of an urban area with dispersed residential and industrial areas and discusses some properties of the equilibrium (future extension). Section 5 summarized and concludes.

\section{Land use restrictions, land prices and the Dutch context}

\subsection{Land use planning and land prices}

A recent literature has presented overwhelming evidence that restrictions on land use can increase house prices. See for instance Kok et al. (2014) who investigate the relationship between land use regulation and land values in the San-Francisco Bay area. A common argument is that the restrictiveness of a local municipality's land use regulation, as indicated by a land use regulation "restrictiveness" index, has a positive effect on the price of land. An example is Glaeser, Gyourko and Saks (2006), who find that zoning and heavy regulation keeps housing supply relatively inelastic, which in turn restricts population growth and keeps housing prices and wages at high levels. Hilber and Vermeulen (2014) show that a change in the planning system had a significant effect on housing construction and use this to investigate the impact of land use restrictions on house prices in the UK, which they find to be substantial. Some researchers also argue that these restrictions have the intention to do this. Hamilton (1978) argues that municipal land regulation can generate monopolistic rent profits, as it exploits the relatively inelastic demand for labor (and consequently for housing) in an urban area. This idea is potentially relevant for the Netherlands where some municipalities have realized considerable benefits from being involved in land transactions. More recently, Fischel (2001) and Hilber and Robert-Nicoud (2013) have examined land use regulations as outcomes of political motives of local land owners. They argue that local owners of developed land benefit from stricter regulations on lands, and therefore they influence planning boards to increase these regulations. Consequently, relatively attractive urban regions with higher provision of amenities tend to be more developed, and therefore they adopt tighter land use regulations. The possibility to introduce rigid land use restrictions that drive up prices is of course related to the size of the 
jurisdiction that introduces them and if they are small, demand is more elastic which will decrease market power. Indeed, Glaeser and Ward (2009) find that when land regulation is applied in urban areas with large number of small local jurisdictions and similar level of amenities, the effect of land regulation on house prices is small and hardly exists.

Alternatively, land use restrictions may be regarded as a means to reduce urban sprawl. Burchfield et al. (2006) investigate the causes of urban sprawl and find that strict regulation, imposed by municipalities, deters developers and has a negative effect on residential development. They also show that strict land regulations encourage developers to develop areas outside the municipal borders, where less regulation exists and development costs are lower. Similarly, Saiz (2010) finds that land use regulation is stronger in areas that experience higher rates of demographic growth and housing prices.

Turner, Haughwout, and van der Klaauw (2011) offer a somewhat different perspective by studying the effects of land use regulations on land values, and measuring their welfare effects. They concentrate on differences in land prices occurring at jurisdictional boundaries and find that a reduction in land use regulation would result in significant benefits, particularly for land owners in the edges of towns, where regulation is most restrictive for new development.

\subsection{The Dutch context: preservation of nature and open space}

The Dutch spatial planning context differs significantly from that in the US and the UK to which most of the existing literature refers. The Netherlands is a densely populated country, especially in the western core region (the so-called Randstad). Restrictive land use regulations have been dominating the national Dutch planning system since the end of WWII. The purpose of these regulations was to direct and accommodate the growing need for urban expansion while conserving the country's natural reserves and agricultural activity. The Dutch "Green Heart" (groene hart), a large agricultural area of approximately 2,400 square kilometer in the middle of the Randstad (the economic center of the Netherlands) was designated in the 1950s to ensure agricultural production in proximity to large population centers (Koomen, Dekkers, \& van Dijk, 2008). ${ }^{3}$ Later on the desire to preserve open (agricultural) space close to the country's largest population centers became the dominant motive for keeping this part of the country dominated by green meadows. In 2004, the Dutch government defined twenty rural and agricultural areas throughout the country, the 'green heart' among them, as "National landscapes" (Nationale Landschappen, see map in appendix A). The national landscape areas were defined in order to protect and preserve agricultural and cultural activity, as well as the environment and landscape in these areas, and therefore they impose heavy restrictions on residential and industrial

\footnotetext{
${ }^{3}$ At the time the food shortages of the winter of 1944-5 were fresh in the planner's memories.
} 
development projects (Kuiper \& de Regt, 2007). Additionally, following EU policy to preserve agricultural activity in naturally less-favored area (LFA), such as peat meadows, river valleys and flood areas, approximately 225,000 hectares of agricultural lands in such areas are designated to remain agricultural in order to maintain the rural landscape and its biodiversity. Owners in such land were compensated by the government with approximately 94 Euro per hectare per year (Kuiper \& de Regt, 2007).

Although this provides suggestive evidence that land use restrictions in the Netherlands are binding, it is not conclusive. The preservation of open or otherwise valuable non-urban space is not the only goal of Dutch land use policy. Equally important is the facilitation and control of urban development so as to serve the needs for residential and urban development. Land use regulations are updated every several years to accommodate changes in these needs. For example, in the course of time the 'green heart' shrunk to 1,800 square kilometers by 1993 (Koomen et al., 2008). On the other hand, the Dutch planning system views regarding nature preservations became stricter, and while urban expansion needs often overruled other restrictions (and were even extended to land reclaimed from the sea), areas defined as nature were strictly preserved (Koomen et al., 2008).

\subsection{The Dutch context: planning of urban extensions}

While strategic spatial planning is dictated by national and provincial level, municipalities are the key player in the Dutch planning system and they have considerable market power within their own jurisdiction. (de Vor \& de Groot, 2011; Hajer \& Zonneveld, 2000; Louw \& Bontekoning, 2007; Louw, van der Krabben, \& Priemus, 2003; Needham, 1997; van Oort, 2004).

Municipalities can determine various land use regulations, since the most legally binding plan in the Dutch system is the local land use plan ("Bestemmingplan") which is determined at the municipal level. Additionally, Dutch municipalities are the main suppliers of land for development (Louw \& Bontekoning, 2007; Needham, 1997), and they are often actively involved in local land markets, to guide spatial planning, to ensure a 'sufficient' supply of housing

It is common practice that municipalities buy the land designated for urban extensions -which is usually in agricultural use ${ }^{4}$ - from the original owners and sell it to developers after converting it in residential or industrial land. The revenues are used to cover the servicing and development costs but before the onset of the financial crisis in 2008 many municipalities realized large

\footnotetext{
${ }^{4}$ However, developers have also followed this strategy, which is all the more attractive to them since Dutch law stipulates that a land owner who is able to develop the land (within the limits of the local zoning plan) has the right to do so. Developers thus try to benefit from the increase in the value of land associated with the conversion to residential or industrial use and ensure themselves of new projects.
} 
amounts of revenues from their land departments (Buitelaar, 2010; Louw et al., 2003; Needham, 1997). In the Netherlands the growth of urban areas is realized through planned large scale extensions that are usually realized by a small number of commercial developers who cooperate closely with the municipalities. . However, the number of municipalities is large - 408 in $2013-$ and different municipalities often compose different parts of the same urban agglomeration. Moreover, the fact that municipalities have a dominant position on the local land market does not necessarily imply that they act like a profit maximizing monopolist.

Since the early 1990's, new residential development in the Netherlands is largely directed by the Fourth Memorandum for Spatial Planning Extra (abbreviated as 'VINEX'). Issued in 1991, the VINEX plan for new residential neighborhoods was conceived by the Dutch government in order to accommodate the housing needs of the growing Dutch population. It directed the construction of approximately 830,000 affordable housing units, of which 455,000 were planned in specifically designated "VINEX development areas" (Boeijenga, Mensink, \& Grootens, 2008; Koomen et al., 2008; Lörzing, Klemm, van Leeuwen, \& Soekimin, 2006; Rietveld \& Wagtendonk, 2004). The VINEX sites were located close to existing urban areas (see map in appendix B). To ensure the realization of these plans the national governments had stimulated regional coordination of residential development plans through covenants by municipalities. The VINEX sites were thus agreed upon as the focal points of residential construction activities within broader areas, which implied that outside these sites little residential development would take place.

Along with the expected expansion of residential development (as part of the VINEX plan), commercial interest in such developments grew as Dutch housing policy underwent additional deregulation in the early 1990's, with the withdrawal of government subsidies to newly developed social residential housing, and a shift of the responsibility for adequate housing from the central government to local municipalities and commercial developers (Dieleman, 1999; Priemus \& Louw, 2002; Vermeulen \& Rouwendal, 2007). Since the VINEX plan defined where the development would take place, restricted the development in other areas and directed most of the residential development to the owner-occupied sector, investment in lands in the designated areas, still mainly agricultural at the time that the VINEX plan was published, offered low risk and high potential gains for commercial developers (Needham, 1997). Moreover the Dutch law stipulates that the owner of the land has the right to develop it ${ }^{5}$ (within the limits imposed by the planning system) which implies that investments in land by developers also guaranteed a strong market position for them when development would actually take place. Such investments occurred indeed on a large scale (Louw et al., 2003; Needham, 1997; Priemus \& Louw, 2002). The price of residential land in VINEX areas is usually determined by the 'residual value

\footnotetext{
${ }^{5}$ Provided the owner is qualified to do so, as developers (of course) are, but farmers in general not.
} 
method.' That is, the construction costs are subtracted from the expected market prices of the houses to be constructed. The developers buy the land from the municipality at this residual value, construct the houses and sell them. Construction will only start when a substantial part of the planned houses ( $70 \%$ is a rule of thumb) is sold to households. If there is insufficient interest in the planned houses, the plan will be reconsidered. It is obvious that this procedure implies downward rigidity of the prices of new houses. The complicated procedures involved in planning large scale extensions of urban area tends to make housing supply inelastic in times of increasing prices, while the downward price rigidity tends to make it very sensitive to decreasing prices (Vermeulen and Rouwendal, 2007). It is important to note that the involvement of the national government focused on residential development, even though the VINEX plan also required that employment centers would be constructed in short commuting distance from the new neighborhoods in order to reduce car mobility (Boeijenga et al., 2008; Kruythoff \& Teule, 1997). ${ }^{6}$

In contrast with residential lands, the responsibility for allocation of industrial land remained almost exclusively in the hands of the municipalities, which determine the allocation based on forecasts for regional employment demand (de Vor \& de Groot, 2011; Louw \& Bontekoning, 2007; Needham \& Louw, 2006). The contrast with the government-regulated supply of residential lands is reflected when we compare volumes of industrial and residential development- there is a general impression of overprovision of industrial land by municipalities which is related to competition for employment. Between 1996-2010, areas designated for residential use in the Netherlands grew from 213,700 ha to 231,400 ha (8.2\% growth). During the same period, areas designated for industrial uses grew from 59,980 ha to 81,360 ha, a growth rate of almost 36\% (Statistics Netherlands, 2015). Another notable regulatory difference with residential development is that the level of industrial land prices is monitored by the government and the chamber of commerce, who intervene in case of price increase (Needham \& Louw, 2006).

\subsection{Hypotheses}

The discussion in the previous subsection suggests that there are differences in the stringency of land use regulations with respect to residential and industrial development in the Netherlands. However, the picture is not entirely clear, because plans for extensions of urban areas are developed in response to demographic projections and with the explicit target of making decent housing available for every Dutch household. The evidence for local market power of municipalities in residential development is, in our view, quite strong, but also not convincing in

\footnotetext{
${ }^{6}$ This difference is related to the fact that the Dutch constitution stipulates that housing (volkshuisvesting) is the responsibility of the national government.
} 
itself. To provide stronger evidence we will analyze land prices in newly developed urban areas. Hence, the first hypothesis to be tested is that the price of undeveloped land designated for residential use is higher than that of nearby undeveloped land which is designated for industrial use, and that the difference cannot be explained by differences in conversion costs.

As noted above, preservation of open space, which is usually land in agricultural use, is an important issue in the Netherlands. If this type of land use is restrictive, one would expect the value of the land to which these restrictions refer to be of considerable lower value than land in the proximity on which industrial or residential development is allowed. The difference is that future developments in land rents are reflected in the price of industrial and residential land whereas such developments are absent in agricultural land (Capozza \& Helsley, 1989, 1990). The second hypothesis to be tested is therefore that the price of agricultural land in the proximity of land newly designated for residential or commercial use has a substantially lower value.

Summarizing, we will test the hypotheses that land use restrictions increase the price of newly developed residential land above that of newly developed industrial land, and reduce the price of agricultural land close to below that of newly developed industrial land.

\section{Data and analysis of land values}

\subsection{The prices of residential and industrial land}

In the research and analysis we make use of several data sources regarding land values and uses. The most important of these are the industrial and residential land values made available by Kadaster, the Dutch land registry. ${ }^{7}$ The data includes annual transaction price for industrial land and residential land, in newly developed industrial or residential areas, in 285 municipalities in the Netherlands. The data includes 71,141 residential land transactions and 4,350 industrial land transactions between the years 2003 and 2013. ${ }^{8}$ Transactions per land use were identified based on deed registration and geographic location. Transaction deeds indicate the parcel's land use at the moment of sale. This implies that transactions of land which was converted to other uses soon after sale is still recoded under its initial use at the time of sale. In all transactions included,

\footnotetext{
${ }^{7}$ There are not many papers that analyze land prices in urban areas. See Albouy and Ehrlich (2013) for a recent example. These authors do not find differences in land prices that are related to the type of land use (commercial vs residential).

${ }^{8}$ During the research period, 28,653 residential land transaction (40\% of the sample) were plots in VINEX neighborhoods. In municipalities with VINEX agreements, VINEX transactions form most of the residential land transaction in which the buyer is a private party (see appendix C).
} 
the buyer is a private household or firm. ${ }^{9}$ We removed transactions that did not only refer to land. ${ }^{10}$

A second source of data regarding the values of industrial land was available from the Integral business areas information system (Integraal Bedrijventerrein Informatie Systeem, IBIS) which is operated and maintained by the Dutch government. The IBIS data includes information about the locations of business and industrial areas in the Netherlands, between 1988-2014, and we used this information to confirm the proper land use of transactions in the Kadaster data.

Examination of the land transactions data in several municipalities, in which massive residential and industrial development took place in recent years, resulted in some interesting preliminary findings. Table 1 and Figure 1 describe the median annual land prices for industrial and residential lands, which were sold by municipalities or commercial parties to private parties. The values of lands designated for industrial use are significantly lower. Between the years 20032007 , transaction prices of industrial lands were on average $60 \%$ lower than residential land transactions. In the years $2008-2013$, this difference grew to over $70 \%$ ( $€ 536$ per square meter of residential land, compared with $€ 125$ per square meter for industrial land in 2010).

\section{Table 1 - Summary of annual median land prices}

\begin{tabular}{ccccc} 
Year & Median price, EUR per m2 & N transactions & Median price, EUR per m2 & N transactions \\
\hline 2003 & 304.7 & 11172 & 178.5 & 33 \\
2004 & 334.6 & 13,021 & 160.7 & 168 \\
2005 & 341.3 & 13,240 & 125.0 & 691 \\
2006 & 377.5 & 11,775 & 126.1 & 751 \\
2007 & 422.2 & 7,426 & 131.0 & 804 \\
2008 & 496.0 & 4,235 & 130.9 & 755 \\
2009 & 450.0 & 2,118 & 128.5 & 323 \\
2010 & 536.3 & 2,976 & 125.0 & 300 \\
2011 & 506.3 & 2468 & 128.0 & 250 \\
2012 & 502.1 & 1437 & 137.6 & 156 \\
2013 & 450.0 & 1273 & 108.0 & 119 \\
\hline Total & 372.2 & 71,141 & 130.0 & 4,350
\end{tabular}

\footnotetext{
${ }^{9}$ Transactions in which the buyer is a public body or commercial developer were not included because conversion costs are perhaps not fully included in these transactions and large developers may have market power..

${ }^{10}$ Many transactions refer to land as well as a contract price (aanneemsom) for additional developments and the building to be constructed on the land. Identification of transactions that refer only to land was based on deed research and removal of groups of extreme positive price outliers, which often indicate that the transaction price includes additional irrelevant elements.
} 
Figure 1 - Median annual land transaction prices (2003-2013)

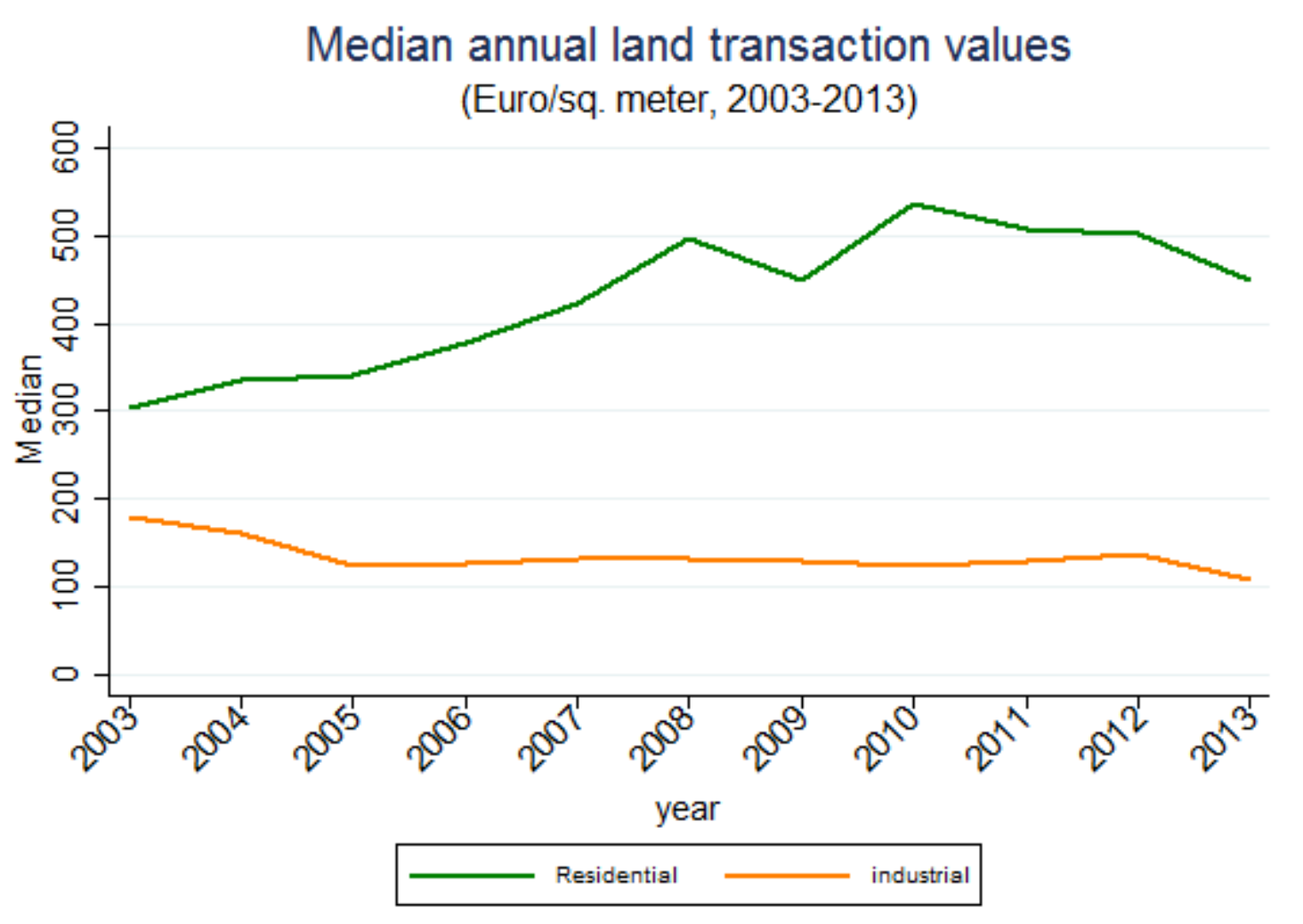

3.4 Estimating the divergence in values of undeveloped residential and industrial lands

To test the equality of the prices of both types of land is a more formal way at the municipal level, we estimate:

$P_{k}^{r}=\alpha+\beta P_{k}^{i}+\epsilon_{k}$

Where $P_{k}^{r}$ is the median price per $\mathrm{m}^{2}$ of newly developed residential land in municipality $k$ and $P_{k}^{i}$ the median price per $\mathrm{m}^{2}$ of industrial land in municipality $k$. If land rents are equal for both residential and industrial uses, we should observe that $\alpha=0$ and $\beta=1$ in the absence of conversion costs. If conversions costs are present $\alpha$ should reflect the difference in conversion costs between residential and industrial land, in a free market equilibrium. Table 2 describes the estimation results of equation, for each sampled year. 
Table 2 - Estimation results for the equality of the prices of residential and industrial land

\begin{tabular}{|c|c|c|c|c|c|c|c|c|c|c|c|}
\hline & $\begin{array}{c}(1) \\
\text { Res. } \\
\text { price, } \\
\text { Year: } \\
2003\end{array}$ & $\begin{array}{c}(2) \\
\text { Res. } \\
\text { price, } \\
\text { Year: } \\
2004\end{array}$ & $\begin{array}{c}(3) \\
\text { Res. } \\
\text { price, } \\
\text { Year: } \\
2005\end{array}$ & $\begin{array}{c}(4) \\
\text { Res. } \\
\text { price, } \\
\text { Year: } \\
2006\end{array}$ & $\begin{array}{c}(5) \\
\text { Res. } \\
\text { price, } \\
\text { Year: } \\
2007\end{array}$ & $\begin{array}{c}(6) \\
\text { Res. } \\
\text { price, } \\
\text { Year: } \\
2008\end{array}$ & $\begin{array}{c}(7) \\
\text { Res. } \\
\text { price, } \\
\text { Year: } \\
2009\end{array}$ & $\begin{array}{c}(8) \\
\text { Res. } \\
\text { price, } \\
\text { Year: } \\
2010\end{array}$ & $\begin{array}{c}(9) \\
\text { Res. } \\
\text { price, } \\
\text { Year: } \\
2011\end{array}$ & $\begin{array}{c}(10) \\
\text { Res. } \\
\text { price, } \\
\text { Year: } \\
2012\end{array}$ & $\begin{array}{c}(11) \\
\text { Res. } \\
\text { price, } \\
\text { Year: } \\
2013\end{array}$ \\
\hline Industrial pr. & $\begin{array}{l}0.645^{* * *} \\
(0.167)\end{array}$ & $\begin{array}{l}0.553^{* * *} \\
(0.0659)\end{array}$ & $\begin{array}{l}0.726^{* * *} \\
(0.0622)\end{array}$ & $\begin{array}{l}0.634^{* * *} \\
(0.0361)\end{array}$ & $\begin{array}{l}0.471^{* * *} \\
(0.0288)\end{array}$ & $\begin{array}{l}0.730^{* * *} \\
(0.0429)\end{array}$ & $\begin{array}{l}0.941^{* * *} \\
(0.0901)\end{array}$ & $\begin{array}{l}0.972^{* * *} \\
(0.147)\end{array}$ & $\begin{array}{l}0.742^{* * *} \\
(0.174)\end{array}$ & $\begin{array}{c}0.438^{* * *} \\
(0.118)\end{array}$ & $\begin{array}{l}1.658^{* * *} \\
(0.330)\end{array}$ \\
\hline Constant & $\begin{array}{l}187.4^{* * *} \\
(37.31)\end{array}$ & $\begin{array}{l}209.6^{* * *} \\
(13.41)\end{array}$ & $\begin{array}{l}205.5^{* * *} \\
(9.264)\end{array}$ & $\begin{array}{l}213.0^{* * *} \\
(7.023)\end{array}$ & $\begin{array}{l}251.0^{* * *} \\
(7.711)\end{array}$ & $\begin{array}{l}223.2^{* * *} \\
(8.053)\end{array}$ & $\begin{array}{l}223.7^{* * *} \\
(17.93)\end{array}$ & $\begin{array}{l}242.1^{* * *} \\
(24.99)\end{array}$ & $\begin{array}{l}254.5^{* * *} \\
(24.58)\end{array}$ & $\begin{array}{l}271.2^{* * *} \\
(26.19)\end{array}$ & $\begin{array}{l}135.9^{* * *} \\
(34.26)\end{array}$ \\
\hline Observations & 31 & 138 & 638 & 705 & 727 & 646 & 234 & 200 & 168 & 101 & 59 \\
\hline Adjusted $R^{2}$ & 0.240 & 0.342 & 0.303 & 0.357 & 0.289 & 0.441 & 0.449 & 0.247 & 0.233 & 0.156 & 0.462 \\
\hline
\end{tabular}

Standard errors in parentheses

${ }^{*} p<0.10,{ }^{* *} p<0.05,{ }^{* * *} p<0.01$

The results in table 2 show that for most years we observe strongly significant coefficients, indicating at we can reject the hypothesis that values of newly developed land, and hence also its rents, are equal for both residential and industrial uses. In most years it appears that $\alpha_{k}$ is positive and that its value is between 200-250 Euros. According to Buitelaar and Witte (2011), the conversion costs of industrial land are approximately $€ 21$ per square meter lower than the conversion costs of residential or mixed land use. The large difference between the land values thus cannot be attributed to differences in conversion costs alone. Although the values of $\beta_{k}$ are often smaller than 1 (and in the years 2009, 2010 and 2013 we cannot reject the null hypothesis that $\beta_{k}=1$ ), the constants $\alpha_{k}$ values are relatively high which ensures that the majority of estimated values lie above the 45 degree line, and the regression results still show that the transaction prices of residential lands is almost always substantially higher than the price of industrial lands.

It is important to note that transactions of land intended for industrial uses generally refer to larger parcels of land (see appendix D). This is likely to be associated with discounts and lower prices per square meters. To account for that, as well as for other unobserved factors that may influence the values of undeveloped land designated for different uses, we conduct an additional analysis and estimate the following model based on the full sample of residential and industrial transactions:

$\ln \left(P_{i, t}\right)=\beta_{0}+\tau R_{i}+\beta_{m} \ln \left(m^{2}{ }_{i, t}\right)+\sum_{t} \beta_{t} Y_{t}+\sum_{k} r e g_{k}+\epsilon_{i, t}$

Where $\ln \left(P_{i}\right)$ is the transaction price in logarithm of either industrial or residential land parcel $i$, $R_{i}$ is a dummy variable which is equal to one if the transaction is of residential land and equals to zero otherwise, the corresponding coefficient $\tau$ is interpreted as the inherent difference in value of undeveloped residential land, compared with the value of undeveloped industrial land in the same municipality and year. $\ln \left(m^{2}{ }_{i, t}\right)$ is the parcel size in logarithm, and $Y_{t}$ and $r e g_{k}$ are dummy variables indicating year $t$ and COROP region (NUTS3) $k$ of transaction respectively. 
The purpose of the region and year variables is to control for possible unobserved local and temporal effects which may influence prices. Although undeveloped parcels of land of different uses are often adjacent to each other, and thus are exposed to similar spatial features and unobserved effects, parcels can also be located in different sites of municipalities (See appendix E). Notwithstanding, the relatively small sizes of Dutch NUTS3 regions implies that the use of municipal dummies still allows for sufficient control for local effects. ${ }^{11}$ The model results are presented in table 3 .

Table 3 - Estimation results: Testing the divergent in prices of residential and industrial land (Including controls)

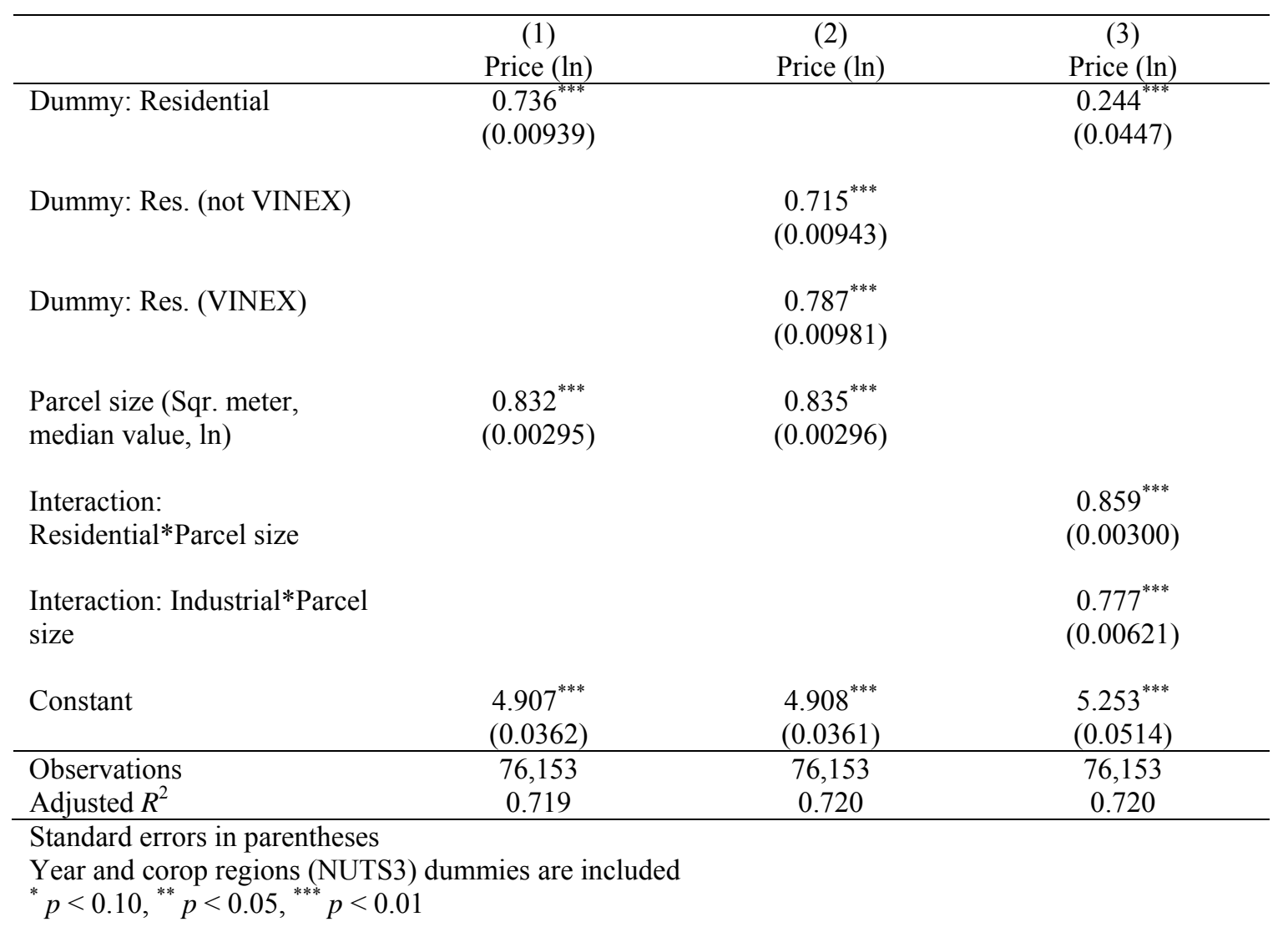

The results in column 1 in table 3 show that prices of undeveloped land designated for residential use are approximately $118 \%$ higher than industrial lands sold in the same municipality and year, and given no difference between uses in parcel size. Residential lands in both VINEX and non-

\footnotetext{
${ }^{11}$ In 2013, the average municipality size was 95 square kilometer. The largest (rural) municipality was 467 sqr.km (Noordoost Polder, in the province of Flevolvand), and the smallest municipality was $7.8 \mathrm{sqr} \mathrm{km} \mathrm{(Westervoort,} \mathrm{in}$ the province of Gelderland).
} 
VINEX areas are found to be sold with similar premiums (column 2).

In column 3 of table 3 we introduce interaction variables between the parcel size and industrial and residential land dummies. Allowing for separate parcel size effects for each designated land use we find that the effect of residential designation of land is still strong and that residential properties are sold at prices higher by approximately $25 \%$. Additionally, the interaction coefficients between land use and parcel size show a similar diverging pattern between industrial and residential land values - a larger coefficient value for parcel sizes of residential lands indicates that the difference between parcel values of different uses becomes greater when parcel sizes increases. In addition to a premium effect of approximately $25 \%$ for residential lands, a one percent increase in parcel size implies a $0.86 \%$ increase in undeveloped residential land values, and $0.77 \%$ increase in undeveloped industrial land values. Interaction coefficient values smaller than 1 correspond with decreasing prices per square meter with parcel size (see appendix D).

\subsection{A comparison with the price of agricultural land}

Agricultural land values are a key component in the values of other land uses, as they reflect the pre-development value of the land, and its alternative use in most cases (Capozza \& Helsley, 1989, 1990). Understanding the price structure of agricultural lands is essential for this analysis, since the vast majority of the recent industrial and residential development in the Netherlands is done on land that was converted from agricultural use. This implies that agricultural lands differ from undeveloped industrial and residential uses only by zoning decisions and land use designation. It may also be possible that other differences between agricultural land values (for example, due to location, potential output and land quality, market accessibility etc.) may influence values of lands that are designated to be developed. To address these issues we provide an analysis of the values of agricultural land, and compare these values to the values of industrial and residential uses in the same geographical region. Data for agricultural land values is also provided by Kadaster, the Dutch land registry, but in contrast to the data on newly developed residential and industrial site we have only aggregated information about agricultural land regarding 26,629 agricultural land transactions in 60 agricultural regions (Landbouwgebied) ${ }^{12}$ in the Netherlands between 2008-2013. ${ }^{13}$

\footnotetext{
12 The agricultural regions are an administrative division that covers the whole country, and often overlaps with municipal borders. Hence, one agricultural region can contain between 1 to 18 different municipalities, with an average of about 9 municipalities for on agricultural region.

${ }^{13}$ In addition to limited availability for the years 2003-2007, the information regarding agricultural land transactions is also limited to region-totals of prices and hectare land sold, and it does not specify individual transaction data. Therefore, the figures presented here refer to mean land values for square meter, per year and agricultural regions.
} 
Table 4 - Agricultural land transaction summary statistics (prices in EUR per square meter)

\begin{tabular}{cccccc} 
Year & $\mathrm{N}$ & $\begin{array}{c}\text { Agricultural } \\
\text { price (mean) }\end{array}$ & $\mathrm{Sd}$ & $\min$ & $\max$ \\
\hline 2008 & 5,383 & 4.39 & 0.93 & 2.71 & 6.83 \\
2009 & 4,266 & 4.57 & 1.06 & 2.38 & 8.8 \\
2010 & 3,854 & 4.6 & 1.02 & 2.66 & 7.19 \\
2011 & 4,141 & 4.91 & 1.18 & 2.33 & 8.44 \\
2012 & 4,241 & 4.8 & 1.17 & 2.12 & 7.68 \\
2013 & 4,744 & 5.03 & 1.1 & 2.5 & 7.74 \\
\hline Total & 26,629 & 4.72 & 1.1 & 2.12 & 8.8
\end{tabular}

Table 4 describes the main price statistics of agricultural land values. The price levels make apparent that extreme price differences exist between agricultural and other uses. While residential and industrial prices vary around 450 and 110 EUR per square meter in 2013 (see table 1), the mean price of agricultural land in that period is 5 Euro per square meter (or about 50,000 per hectare). Though they are relatively low compared to other uses, agricultural land values are not completely homogeneous across regions (see appendix F) and reflect, among other things, differences in productivity. It should be noted that even in areas close to existing cities the price of agricultural land is far below that of industrial and residential land. In 2013, agricultural values varied between 2.5 Euro per square meter in De Marne in the North of the Netherlands, and 7.74 in Zuidelijke IJsselmeerpolders, in the surrounding of Almere.

Most of the transactions of agricultural land refer to parcels that are expected to stay in agricultural use for the foreseeable future. Dekkers (2010) provides an extensive analysis of transactions of agricultural land in the province of North Holland and concludes that prices only show the impact of urban areas in the vicinity in a limited number of areas in which there exist clear expectations that residential or industrial land use will be allowed in the near future. These transactions have hardly an impact on the provincial average of the transaction price for agricultural land. Using data from the Dutch land registry we are able to confirm these findings. Table 5 contains the regression results of agricultural prices (average over agricultural regions) on industrial and residential land prices, while controlling for the share of municipality which is included in a 'national landscape', municipal nature coverage in 1996 and year of transaction and share of municipal area defined as less-favored agricultural land (LFA). Additional factors that affect agricultural land values such as year of transaction and the percentage of municipal area covered by each of the 14 most common soil type in the Netherlands are also added as control variables. It can be argued that the estimation results suffer from reversed causality, particularly between the prices of agricultural lands and of residential and industrial uses. However, due to the Dutch land market characteristics explained above, particularly the land supply restrictions, it 
is unlikely that variance in the value of agricultural lands has a substantial effect on land values of other uses. This is further emphasized when we consider the substantially lower value of land in agricultural uses compared with other uses. Moreover, we control for the quality of agricultural land.

We estimate the following model:

$\ln \left(P_{k, t}^{A}\right)=\beta_{0}+\beta_{r} \ln \left(P_{k}^{r}\right)+\beta_{i} \ln \left(P_{k}^{i}\right)+\sum_{t} \beta_{t} Y_{t}+\sum_{j} \gamma_{j} Z_{j, k}+\epsilon_{k_{t}}$

Where $\ln \left(P_{k, t}^{A}\right)$ is the median price (in log) of agricultural land in year $t$ in agricultural region $k$, $\ln \left(P_{k, t}^{r}\right)$ is the median price (in $\log$ ) of residential land in logarithm in year $t$ in agricultural region $k, \ln \left(P_{k, t}^{i}\right)$ is the median price (in $\log$ ) of industrial land in logarithm in year $t$ in agricultural region $k, Y_{t}$ are year dummies and $Z_{j, k}$ are control variables of land characteristics in each agricultural region, among which are the share of area included in national landscape area, share of areas defined as less-favored agricultural areas, nature coverage in 2008, and prevalence of each of the 14 most common soil types in the Netherlands. To account for possible unobserved time-invariant factors which affect the values of agricultural land we also conduct a fixed-effects estimation of equation (3).

Table 5 - Analysis of agricultural land values

\begin{tabular}{|c|c|c|}
\hline & $\begin{array}{l}\text { (1) } \\
\text { Agricultural price }(\ln )\end{array}$ & $\begin{array}{l}\text { (2) } \\
\text { Agricultural price (ln) }\end{array}$ \\
\hline Residential pr. (ln) & $\begin{array}{l}0.144^{* * *} \\
(0.0393)\end{array}$ & $\begin{array}{c}-0.000949 \\
(0.0334)\end{array}$ \\
\hline Industrial pr. (ln) & $\begin{array}{l}0.0689^{* * *} \\
(0.0250)\end{array}$ & $\begin{array}{l}0.00969 \\
(0.0189)\end{array}$ \\
\hline $\begin{array}{l}\text { Area included in Nationale Landschaap } \\
\text { (share) }\end{array}$ & $\begin{array}{l}-0.000378 \\
(0.000852)\end{array}$ & \\
\hline Less-favored agricultural area (share) & $\begin{array}{l}-0.00566^{* *} \\
(0.00230)\end{array}$ & \\
\hline Nature coverage 2008 (share) & $\begin{array}{l}-0.00367^{* *} \\
(0.00168)\end{array}$ & \\
\hline Constant & $\begin{array}{c}0.432 \\
(0.295)\end{array}$ & $\begin{array}{l}1.381^{* * *} \\
(0.225)\end{array}$ \\
\hline $\begin{array}{l}\text { Observations } \\
\text { Adjusted } R^{2}\end{array}$ & $\begin{array}{c}292 \\
0.541 \\
\end{array}$ & $\begin{array}{c}292 \\
-0.057 \\
\end{array}$ \\
\hline $\begin{array}{l}\text {-Standard errors in parentheses } \\
\text {-Year dummies are included. } \\
\text {-Additional control variables included fo } \\
\text { soil-type in the Netherlands. } \\
{ }^{*} p<0.10,{ }^{* *} p<0.05,{ }^{* * *} p<0.01\end{array}$ & ntage of municipal area & y each of the 14 most \\
\hline
\end{tabular}


Positive and significant coefficients of residential and industrial land values suggest that in municipalities where residential and industrial values are higher by $1 \%$, the price of agricultural land tends to be higher by $0.144 \%$ and $0.69 \%$ respectively. However, when agricultural areas fixed-effects are introduced (column 2), this effect becomes statistically insignificant.

These findings imply that in areas that experience higher industrial and residential price levels, expectations for possible future developments increase agricultural land values. These expectations can be either for a municipal decision to convert lands to industrial uses, or for a possible eventual policy change and relaxation of residential development restrictions.

Although the effect of high land values is strong and statistically significant, the price of agricultural land remains negligible compared with the values of undeveloped land designated for future development. Moreover, the effect of developed land values on agricultural lands is no longer significant when fixed-effects are considered, implying that changes in residential and industrial prices are uncorrelated with trends in agricultural prices, and possible correlation with unobserved regional effects.

\subsection{Interpretation}

In summary, we find a clear pattern in the land prices studied: newly developed residential land has the highest price and agricultural land the lowest. The price difference between newly developed residential and industrial land, as well as the price difference between agricultural and undeveloped industrial lands, cannot be ascribed to differences in conversion costs. We thus find that land use policy in the Netherlands is restrictive in at least two ways: residential development is more limited than industrial development and land that is zoned to be exclusively agricultural is in general expected to be agricultural for the foreseeable future.

These finding are in line with our earlier description of the planning of new residential and industrial areas. In the early 1990s housing policy had just shifted towards the construction of owner-occupied housing and it was initially doubtful if this would be feasible. Local and national governments were concerned about the attractiveness of the residential construction market for private parties. It was realized that the market could be supported by restricting extensions to built-up areas to a limited number of sites. The planned large-scale developments on these sites were realized ${ }^{14}$ by one or a few large developers operating in close cooperation with the municipality. The limited number of actors involved facilitated the control of the development

\footnotetext{
${ }^{14}$ Note that this practice can be viewed as consistent with the main purposes of the Dutch spatial development policy: preserve nature and open space and realize an orderly pattern of urban growth, avoiding sprawl.
} 
process so as to ensure the realization of the target prices. ${ }^{15}$ After some time it became clear that this organization of the market enabled the realization of substantial amounts of housing. The target prices for newly constructed housing followed the course of the house prices which were rapidly increasing in real terms in the course of the $1990 \mathrm{~s} .{ }^{16}$ Construction cost did not increase that rapidly and many Dutch municipalities engaged in what was called 'active land policy.' At the time, this contributed substantially to their budget. Developers could ensure their participation in large-scale new developments by buying land at sites that would probably be designated for residential use in the future and did so on a large scale. ${ }^{17}$ This resulted in house prices increasing substantially faster than construction costs, and increasing 'residual' land prices.

There was no corresponding development on the market for residential land. The allocation of land to industrial use remained largely in the responsibility of local authorities, and the values of this type of land were only monitored by the national government in the interest of employment growth, which implies that the concern was that they could be too high. The general impression is that there is fierce competition between nearby municipalities for attracting employment by offering industrial land at low prices.

Our findings with respect to agricultural land are in line with those of Dekkers (2010). The price of this type of land is only a small fraction of that of newly developed industrial or residential land in the vicinity and although it reflects variation in the prices for these alternative uses, it stays on average at a much lower level.

We must therefore conclude that Dutch land use policy is restrictive in at least two respects: residential development is much more limited than industrial development and although land use planning facilitates the growth of urban areas, agricultural land does in general not reflect anticipation of conversion to urban use in the foreseeable future.

\section{Conclusion}

In this paper we have documented that spatial planning in the Netherlands leads to a segmented land market in which the prices of agricultural, and newly developed industrial and residential

\footnotetext{
${ }^{15}$ As noted above, these were derived from actual market prices. The residual value method obliged the developers (who sold the houses) to pay the residual (land) value to the municipality. Selling below the target price therefore implied that construction costs were not fully covered.

${ }^{16}$ Increasing real incomes - partly due to increasing labor force participation of married women - and gradually decreasing mortgage interest rates caused a substantial increase in the borrowing capacity of Dutch households which increased the price they could afford to pay for housing (Boelhouwer \& Schiffer, 2015).

${ }^{17}$ In the Netherlands the owner of the land has the right to develop it within the constraints of the land use plan if he is qualified to do so. Developers are clearly qualified for housing construction. In contrast, farmers are usually not and they can be forced to sell their land if it is designated as part of a residential area.
} 
land differ substantially. The price of residential land is much higher than the sum of the value of agricultural land and conversion costs. The price of industrial land, which is supplied in a relatively unrestricted way, is substantially lower, but still an order of magnitude higher than the price of nearby agricultural land.

The primary aim of this analysis was to document this fact. It may be observed that our analysis does not directly reveal any costs or benefits of spatial planning. Benefits, for instance in the form of protecting open space, surely exist, although it may be doubted if the high price of urban residential land can be justified by the protection of open space that results from it. ${ }^{18}$ Costs are also present. For instance, it is hard to see why open space should be protected by tightening the supply of residential land much more than that of industrial land. The large difference between the prices for newly developed residential and industrial land signals misallocation. If one thinks that the supply of industrial land is appropriate, then not enough land for residential use is provided. Conversely, if one thinks that the level of residential land prices is appropriate for maximizing the benefits of land use planning, it seems hard to avoid the consequence that the supply of industrial land should be tightened so as to bring its price at a comparable value. ${ }^{19}$ If the price of newly developed residential land is higher than optimal from a social welfare maximizing point of view, Dutch households pay too much for their houses. Note that the price of newly developed land is reflected in the price of all housing. To be sure, the Dutch planning system has been able to keep owner-occupied housing affordable for most households while real house prices increased substantially in the 1990s and the early $2000 \mathrm{~s} .{ }^{20}$ However, additional supply of residential land could have resulted in house prices following the development of construction cost, which would have resulted in a substantial benefit for many home buyers. A lower price of newly developed residential land would also be reflected in the housing type composition of new neighborhoods, and construction in lower density should be expected (Ahlfeldt \& Mcmillen, 2014; Epple, Gordon, \& Sieg, 2010).

\section{References}

Ahlfeldt, G. M., \& Mcmillen, D. P. (2014). New Estimates of the Elasticity of Substitution of Land for Capital.

Albouy, D., \& Ehrlich, G. (2013). The Distribution of Urban Land Values: Evidence from Market Transactions. Mimeograph, University of Illinois.

Boeijenga, J., Mensink, J., \& Grootens, J. (2008). Vinex Atlas. Rotterdam 010.

\footnotetext{
${ }^{18}$ See Vermeulen and Rouwendal (2014).

${ }^{19}$ As far as we know there is no support for this point of view in the Netherlands, which may be interpreted as suggesting that the price of residential land is too high.

${ }^{20}$ See Renes et al. (200.)
} 
Boelhouwer, P., \& Schiffer, K. (2015). Kopers verdienen meer! (in Dutch).

Buitelaar, E. (2010). Window on the Netherlands: Cracks in the Myth: Challenges To Land Policy in the Netherlands. Tijdschrift Voor Economische En Sociale Geografie, 101(3), 349-356.

Buitelaar, E., \& Witte, P. (2011). Financiering van gebiedsontwikkeling een empirische analyse van grondexploitaties.

Burchfield, M., \& Overman, H. (2006). Causes of sprawl: A portrait from space. The Quarterly Journal of Economics, 121(2), 587-633.

Capozza, D. R., \& Helsley, R. W. (1989). The fundamentals of land prices and urban growth. Journal of Urban Economics, 306, 295-306.

Capozza, D. R., \& Helsley, R. W. (1990). The stochastic city. Journal of Urban Economics, 28(2), 187-203.

de Vor, F., \& de Groot, H. L. F. (2011). The Impact of Industrial Sites on Residential Property Values: A Hedonic Pricing Analysis from the Netherlands. Regional Studies, 45(February 2015), 609-623.

Dekkers, J. E. C. (2010). Externalities, land use planning and urban expansion.

Dieleman, F. M. (1999). The Impact of Housing Policy Changes on Housing Associations: Experiences in the Netherlands. Housing Studies, 14(2), 251-259.

Epple, D., Gordon, B., \& Sieg, H. (2010). A New Approach to Estimating the Production Function for Housing : Appendices. American Economic Review, 100(June), 905-924.

Fischel, W. A. (2001). The homevoter hypothesis: How home values influence local government taxation, school finance, and land-use policies. Cambridge, MA: Harvard University Press.

Glaeser, E. L., Gyourko, J., \& Saks, R. (2006). Urban growth and housing supply. Journal of Economic Geography, 6(1), 71-89.

Glaeser, E. L., \& Ward, B. a. (2009). The causes and consequences of land use regulation: Evidence from Greater Boston. Journal of Urban Economics, 65(3), 265-278.

Hajer, M., \& Zonneveld, W. (2000). Spatial Planning in the Network Society-Rethinking the Principles of Planning in the Netherlands. European Planning Studies, 8(3), 337-355.

Hamilton, B. (1978). Zoning and the exercise of monopoly power. Journal of Urban Economics, 116-130.

Hilber, C. A. L., \& Robert-Nicoud, F. (2013). On the origins of land use regulations: Theory and evidence from US metro areas. Journal of Urban Economics, 75, 29-43.

Hilber, C. A. L., \& Vermeulen, W. (2014). The Impact Of Supply Constraints On House Prices In England. The Economic Journal, 2012(April).

Kok, N., Monkkonen, P., \& Quigley, J. M. (2014). Land use regulations and the value of land and housing: An intra-metropolitan analysis. Journal of Urban Economics, 81, 136-148.

Koomen, E., Dekkers, J., \& van Dijk, T. (2008). Open-space preservation in the Netherlands: 
Planning, practice and prospects. Land Use Policy, 25(3), 361-377.

Kruythoff, H., \& Teule, R. (1997). Vinex policy moves into the implementation phase. Netherlands Journal of Housing and the Built Environment, 12(1), 113-133.

Kuiper, R., \& de Regt, W. J. (2007). Landbouw in de Nationale Landschappen (No. 500074004).

Lörzing, H., Klemm, W., van Leeuwen, M., \& Soekimin, S. (2006). VINEX! Een morfologische verkenning. Ruimtelijke Planbureau, The Hague.

Louw, E., \& Bontekoning, Y. (2007). Planning of industrial land inf the Netherlands: Its rationales and consequences. Tijdschrift Voor Economische En Sociale Geografie, 98(1), 121-129.

Louw, E., van der Krabben, E., \& Priemus, H. (2003). Spatial development policy: Changing roles for local and regional authorities in the Netherlands. Land Use Policy, 20, 357-366.

Needham, B. (1997). Land policy in the Netherlands. Tijdschrift Voor Economische En Sociale Geografie, 88(3), 291-296.

Needham, B., \& Louw, E. (2006). Institutional Economics and Policies for Changing Land Markets: The Case of Industrial Estates in the Netherlands. Journal of Property Research, 23(1), 75-90.

Priemus, H., \& Louw, E. (2002). Recovery of land costs: a land policy instrument missing in the Netherlands? European Journal of Housing Policy, 2(2), 127-146.

Rietveld, P., \& Wagtendonk, A. J. (2004). The location of new residential areas and the preservation of open space: experiences in the Netherlands. Environment and Planning A, 36(11), 2047-2063.

Saiz, A. (2010). The Geographic Determinants of Housing Supply. The Quarterly Journal of Economics, 125(3), 1253-1296.

Turner, M. A., Haughwout, A., \& van der Klaauw, W. (2011). Land use regulation and welfare. Federal Reserve Board of New York.

van Oort, F. G. (2004). Urban growth and innovation: Spatially bounded externalities in the Netherlands. Gower Publishing, Ltd.

Vermeulen, W., \& Rouwendal, J. (2007). Housing supply in the Netherlands (No. 058/3). 
A. Land development restrictions in the Netherlands:

National landscapes and Less-Favored Areas (LFA):
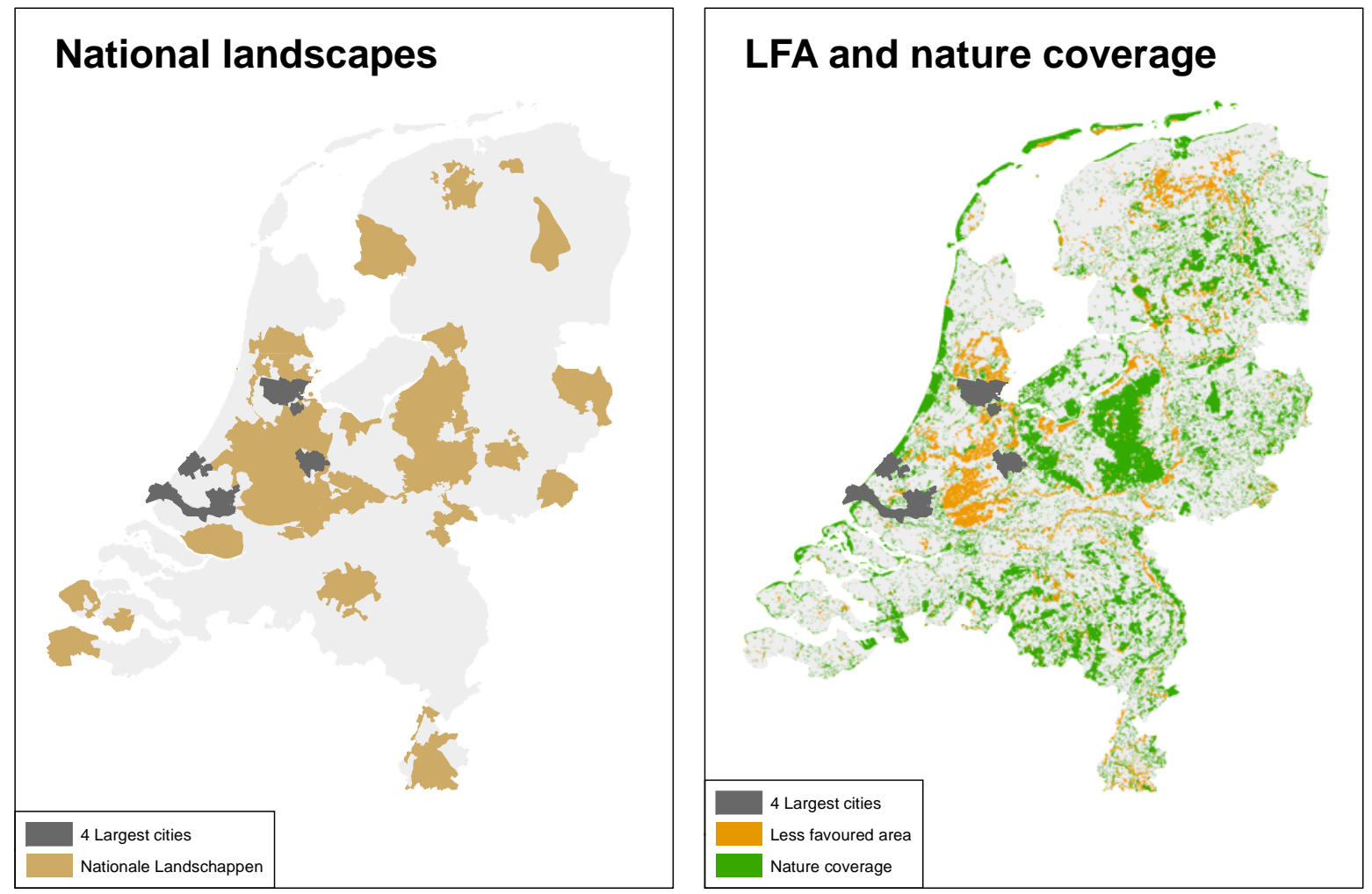
B. VINEX neighborhood and new industrial locations in the Netherlands
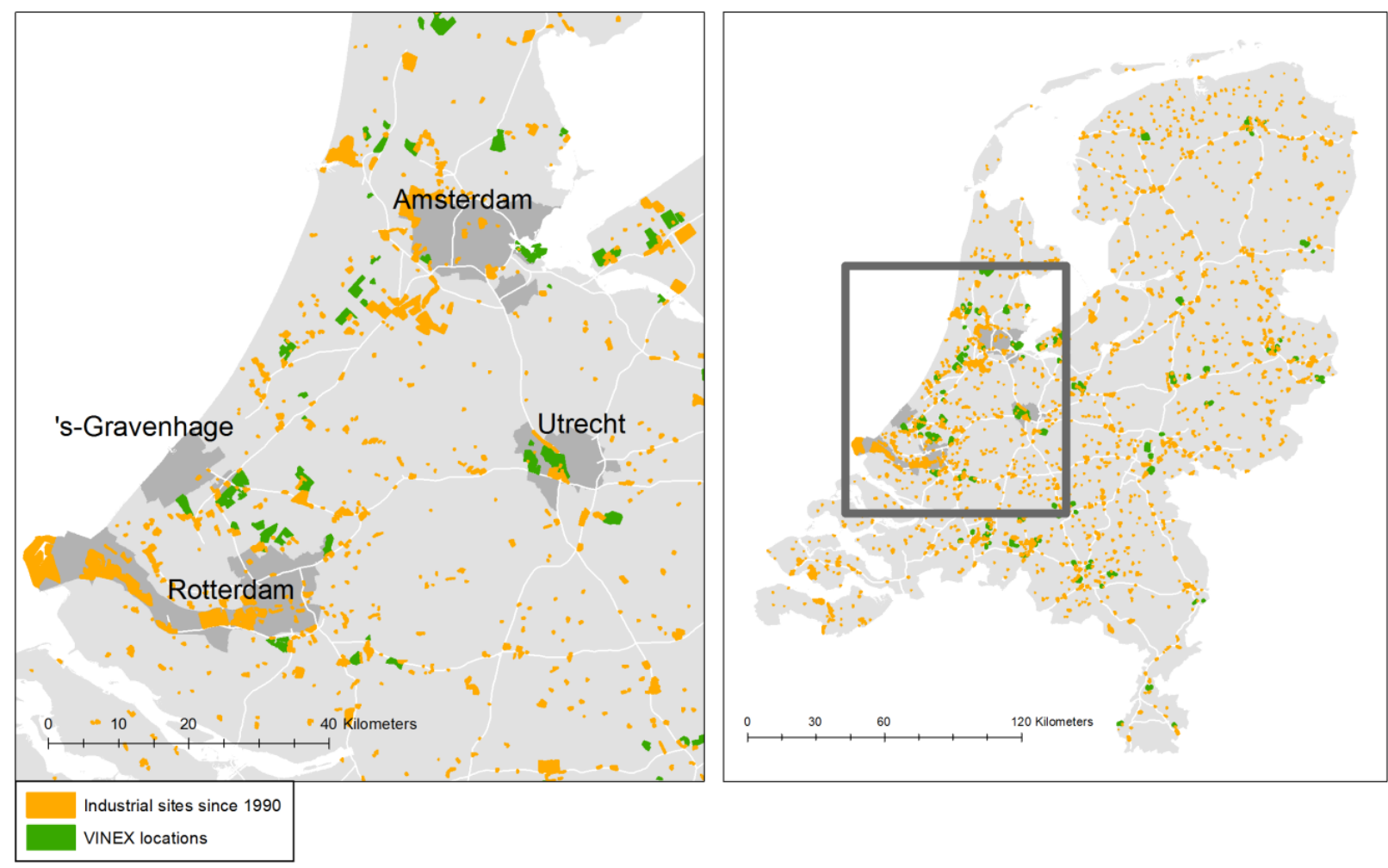

sites since 1990

VINEX locations 
C. Share of residential land transactions in VINEX neighborhoods, in municipalities with VINEX agreements

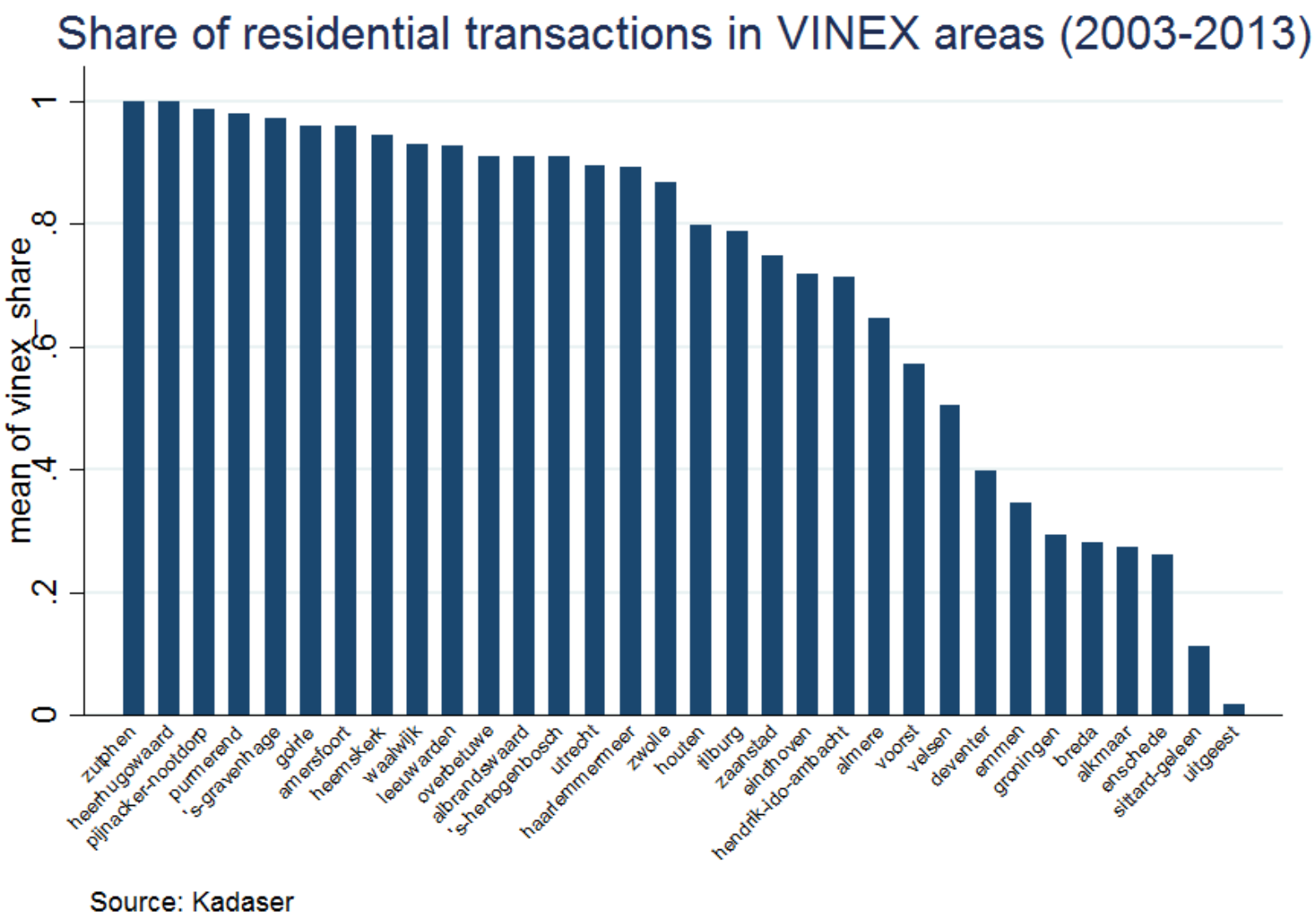


D. Transaction prices per square meter of residential and industrial lands (ln) and corresponding parcel sizes $(\ln )(2003-2013)$

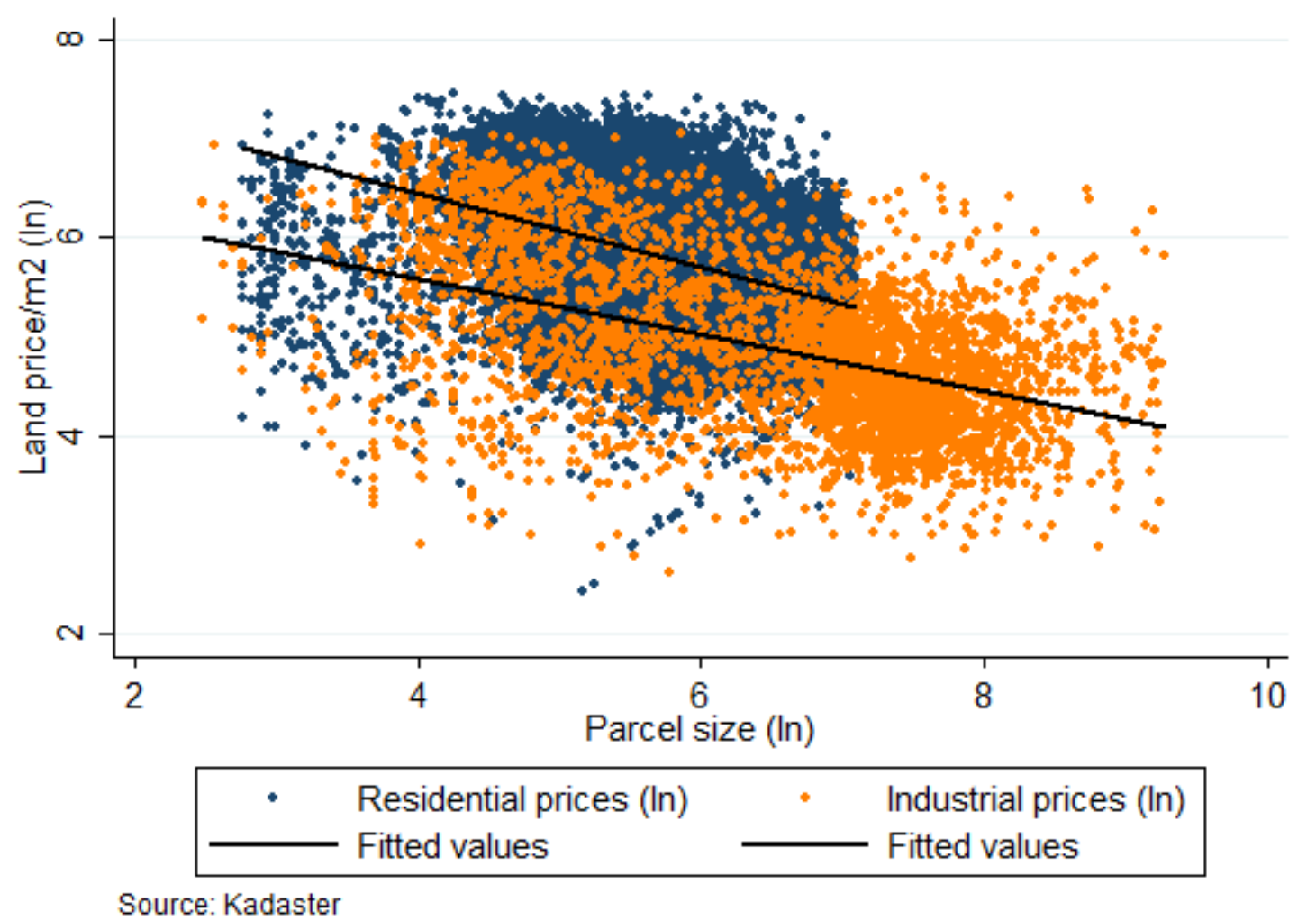


E. Industrial areas and new residential development in VINEX neighborhoods - City of Almere

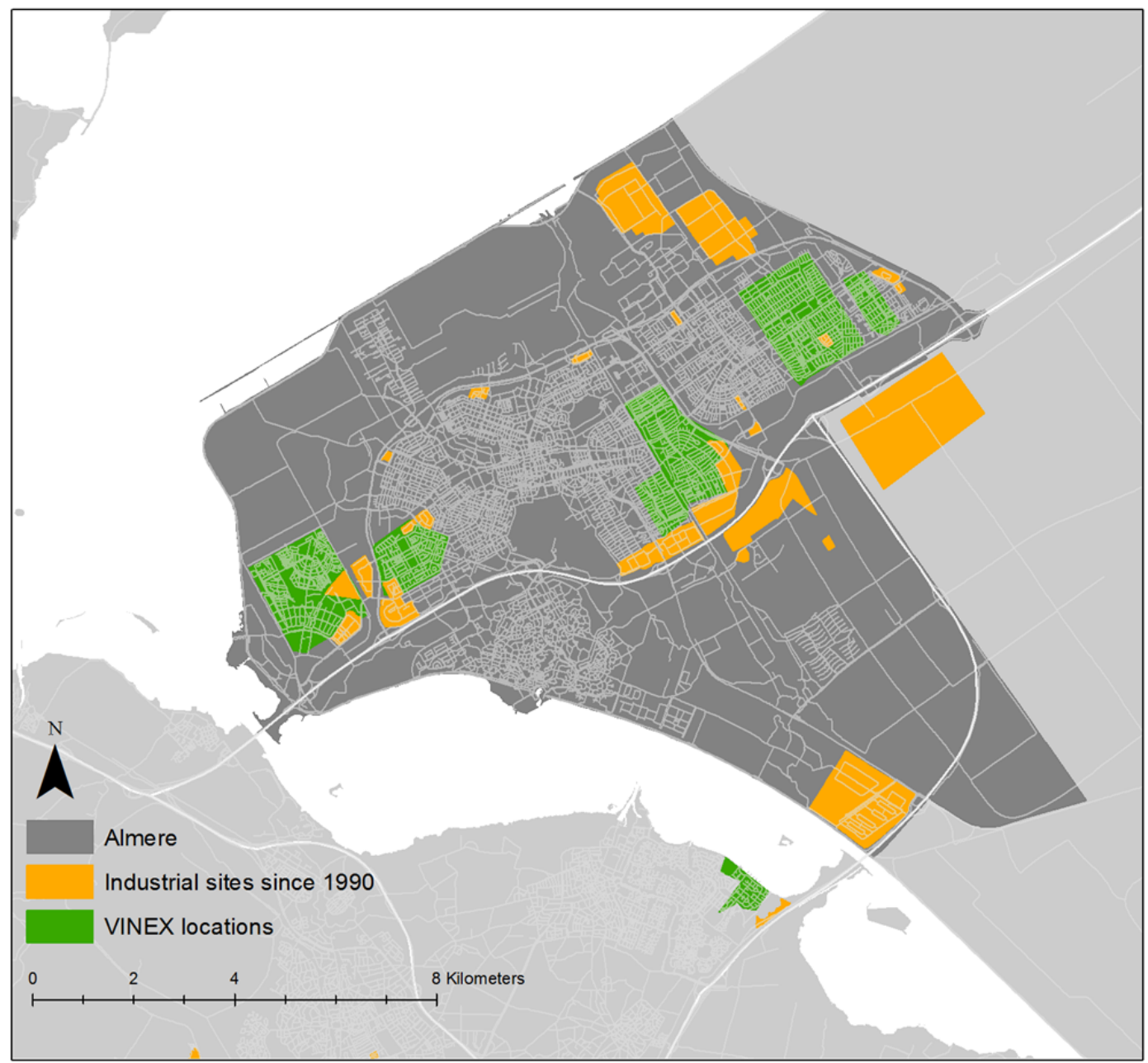


